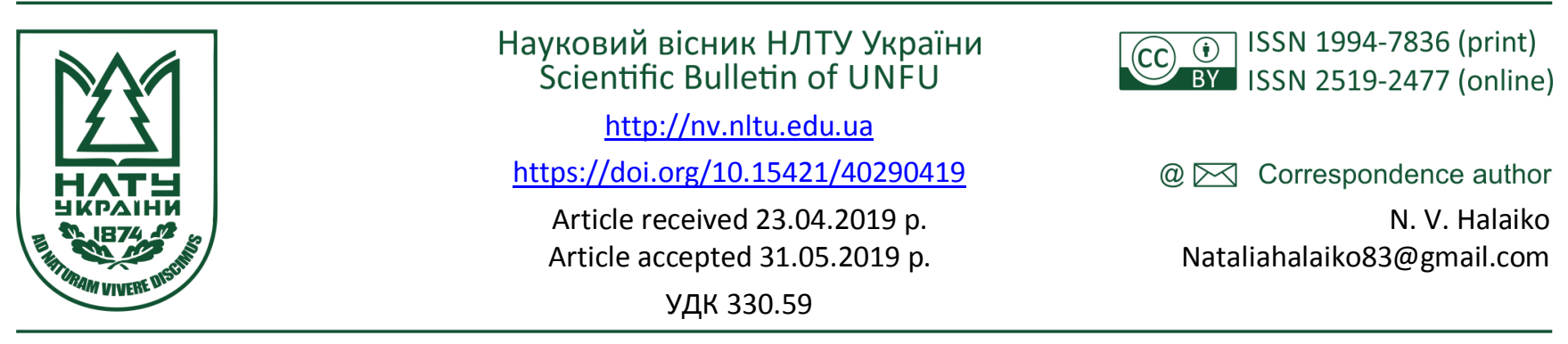

Н. В. Галайко, О. О. Столяренко

Львівський державний університет внутрішніх справ, м. Львів, Украӥна

\title{
ВПЛИВ СОЦІАЛЬНИХ ТА ПСИХОЛОГІЧНИХ ЧИННИКІВ НА ФІНАНСОВУ БЕЗПЕКУ ОСОБИ
}

Розглянуто підходи до трактування поняття "фінансова безпека особи" та подано власне тлумачення цієї категорії. Зазначено, що забезпечення фінансової безпеки особи має вагомий вплив на фінансову безпеку держави і навпаки. При дослідженні факторів впливу на фінансову безпеку особи, сконцентровано увагу на соціальних і психологічних чинниках. Розраховано інтегральний індекс фінансової безпеки особи. Для визначення цього узагальнюючого показника взято до уваги такі індикатори, як рівень прожиткового мінімуму, розмір оплати праці (середня заробітна плата), величина сукупних доходів на одну особу, розшарування населення за рівнем доходів (квінтильний коефіцієнт фондів) та розмір ВВП на душу населення, які досліджували в динаміці впродовж 2009-2018 рр. Встановлено чітку залежність між фінансовою безпекою особи та її психологічною безпекою, зазначено, що тут існує взаємозв'язок. Звернено увагу на те, що на фінансову та психологічну безпеку особи має вагомий вплив ставлення людини до грошей, ії здатність до заощадження, пошуку джерел фінансування та досліджено чотири тенденції формування монетарної культури. Сформовано власні висновки та наведено основні напрями підвищення рівня фінансової та психологічної безпеки особи.

Ключові слова: фінансова безпека особа; психологічна безпека особи; інтегральний індекс фінансової безпеки особи; ставлення людини до грошей; рівень прожиткового мінімуму; розмір оплати праці.

Вступ. Забезпечення фінансової безпеки особи має вагомий вплив на фінансову безпеку держави, бо в умовах нестабільності неможливо вирішити економічні проблеми не забезпечивши фінансову безпеку громадян. Також варто зауважити, що особливе значення під час дослідження фінансової безпеки особи мають соціальні та психологічні чинники. Оскільки величина сукупних доходів на душу населення, рівень оплати праці, психологічне ставлення до грошей та заборгованості - це чинники, які безумовно впливають на фінансову безпеку особи та формують її подальший добробут.

Питання фінансової безпеки досліджувало багато вчених, зокрема Л. Абалкін, О. Барановський, І. Бланк, А. Єрмошенко та ін. На вплив психологічних чинників на фінансову безпеку, психологію грошей та економічну психологію у своїх працях сконцентрувалися такі науковці, як В. Москаленко, А. Федько, Р. Агузумцев. Однак питання фінансової безпеки особи, визначення чинників впливу на фінансову безпеку особу та ролі при цьому психологічної безпеки досліджено частково. Саме тому потрібно провести грунтовний аналіз цієї проблеми, визначити узагальнюючий показник, за яким визначатиметься рівень фінансової безпеки, та встановити, яке місце при цьому належить психологічній безпеці особи.

Метою роботи є аналіз впливу соціальних та психологічних чинників на стан фінансової безпеки особи.

Виклад основних положень роботи. Проблеми забезпечення безпеки об'єктивно зачіпають всі сторони нашого життя і мають багатоплановий характер. 3 розвитком соціуму категорія "безпека" зазнала істотних змін. Зміни, що відбуваються в суспільстві, зокрема в соціально-економічній, політичній, духовно-моральній, інформаційній сферах, з одного боку, створюють якісно нові можливості вибору життєвого шляху, з іншого надають деструктивний вплив, що зумовлює у багатьох людей дезорієнтацію у сучасній соціальній ситуації, негативно позначаючись на планах, цілях та якості життя, підвищують при цьому соціальну напруженість і призводять до наростання неблагополуччя. Варто зазначити, що головною структурною одиницею будь-якого сегменту суспільства $є$ особистість, тому необхідно дослідити проблему забезпечення фінансової безпеки стосовно окремої людини.

Науковці розглядають фінансову безпеку особи як соціально-економічну категорію, яка показує рівень матеріального забезпечення для задоволення первинних потреб, а також як важливу складову соціальної безпеки та один із найважливіших показників рівня життя населення (Papusha, 2011, p. 230-234). На нашу думку, фінансова безпека особи - це показник, який би вказував на забезпечення особи фінансовими ресурсами в тому розмірі, за якого людина може задовольнити свої мінімальні потреби та має змогу захиститися від впливу зовнішніх і внутрішніх ризиків.

Статистичне оцінювання фінансового стану особи вимагає формування повної та репрезентативної системи показників, яка дала б змогу кількісно охарактеризу-

\section{Інформація про авторів:}

Галайко Наталія Володимирівна, ст. викладач, кафедра економіки та економічної безпеки. Email: Nataliahalaiko83@gmail.com Столяренко Олена Олексіївна, ст. викладач, кафедра економіки та економічної безпеки. Email: olenkasto@ukr.net

Цитування за ДСту: Галайко Н. В., Столяренко О. О. Вплив соціальних та психологічних чинників на фінансову безпеку особи. Науковий вісник НЛТУ України. 2019, т. 29, № 4. С. 89-92.

Citation APA: Halaiko, N. V., \& Stoliarenko, O. O. (2019). Influence of social and psychological factors on financial safety of a person. Scientific Bulletin of UNFU, 29(4), 89-92. https://doi.org/10.15421/40290419 
вати об'єкт дослідження для визначення реального стану рівня фінансового забезпечення населення країни. До основних показників, що визначають рівень фінансової безпеки особи (таблиця), можна віднести (Papusha, 2011; Yermoshenko, 2015; Veb-storinka, 2019):

1. Рівень прожиткового мінімуму (розмір прожиткового мінімуму встановлюють на основі споживчого кошика, оскільки за його допомогою визначають набір продуктів та послуг першої необхідності). Розмір прожиткового мінімуму за перше півріччя 2018 р. становив 1700 грн, а за перше півріччя 2019 р. - 1853 грн.

2. Розмір оплати праці (для особи, котра працює, основним джерелом доходів $є$ заробітна плата і саме іiі розмір визначає купівельну спроможність працівника). Середня заробітна плата в Україні в січні 2018 р. становила 7711 грн, а в грудні 2018 р. - 10573 грн.

3. Величина сукупних доходів на душу населення та їхня структура. В Україні структура доходів населення майже однакова і до її складу входять заробітна плата, прибуток та змішаний дохід, доходи від власності, соціальні допомоги та інші одержані поточні трансферти. Середній розмір призначеної субсидії на одне домогосподарство у грудні 2018 р. зменшився порівняно з відповідним періодом 2017 p. на $28,2 \%$ і становив 713,0 грн.

4. Розшарування населення за рівнем доходів та витрат.

5. Розмір ВВП на душу населення. В Україні цей показник у II кварталі 2018 р. становить 19,074 тис. грн.

Для визначення інтегрального індексу фінансової безпеки особи необхідно: сформувати множину індикаторів, які впливають на фінансову безпеку особи; обчислити значення даних індикаторів; нормалізувати індикатори; визначити вагові коефіцієнти; розрахувати інтегральний індекс.

На наш погляд, основними індикаторами, що мають вплив на фінансову безпеку особи, $є$ : рівень прожиткового мінімуму, розмір оплати праці (середня заробітна плата), величина сукупних доходів на одну особу, розшарування населення за рівнем доходів та розмір ВВП на душу населення (квінтильний коефіцієнт фондів співвідношення сумарних доходів найбільш та найменш забезпечених $20 \%$ населення, ранжованого за показником середньодушових еквівалентних доходів (Zavhorodnia, 2014, p. 193)).

Таблиця. Показники впливу на фінансову безпеку особи

\begin{tabular}{|c|c|c|c|c|c|}
\hline \multirow{2}{*}{ Рік } & $\begin{array}{c}\text { Рівень } \\
\text { прожит- } \\
\begin{array}{c}\text { кового мі- } \\
\text { німуму, } \\
\text { дол. США }\end{array}\end{array}$ & $\begin{array}{c}\text { Середня } \\
\text { полобітна США } \\
\text { плата, }\end{array}$ & $\begin{array}{c}\text { Величина } \\
\text { сукупних } \\
\text { доходів, } \\
\text { дол. США }\end{array}$ & $\begin{array}{c}\text { Розмір } \\
\text { ВВП на } \\
\text { душу на- } \\
\text { селення, } \\
\text { дол. США }\end{array}$ & $\begin{array}{c}\text { Квінтиль- } \\
\text { ний ко- } \\
\text { ефіцієнт } \\
\text { фондів }\end{array}$ \\
\hline 2009 & 105,85 & 244,54 & 1844,02 & 2544,46 & 3,6 \\
\hline 2010 & 110,27 & 283,56 & 2329,70 & 2974,30 & 3,5 \\
\hline 2011 & 119,81 & 332,90 & 2720,26 & 3622,40 & 3,4 \\
\hline 2012 & 137,03 & 380,55 & 3154,30 & 3868,35 & 3,2 \\
\hline 2013 & 147,13 & 410,61 & 3342,85 & 4002,09 & 3,3 \\
\hline 2014 & 98,91 & 292,69 & 2252,51 & 3013,82 & 3,1 \\
\hline 2015 & 60,85 & 191,94 & 1455,11 & 2114,29 & 3,2 \\
\hline 2016 & 60,42 & 202,83 & 1451,09 & 2185,78 & 3,0 \\
\hline 2017 & 63,87 & 266,90 & 1775,94 & 2638,36 & 3,3 \\
\hline 2018 & 68,11 & 325,87 & 2102,47 & 3094,80 & 3,2 \\
\hline
\end{tabular}
2019)

Примітка: *розрахували автори на основі (Veb-storinka,

Як бачимо, рівень прожиткового мінімуму впродовж 2009-2013 рр. зріс на 41,28 дол. США, або на $39 \%$. Найбільш критична ситуація за ключовими показниками фінансової безпеки особи склалася у 20152016 рр. Якщо порівняти значення основних індикато- рів 32013 р., то бачимо, що рівень прожиткового мінімуму знизився у 2016 р. на 84,71 дол. США або на $57,6 \%$, середня заробітна плата у 2015 р. зменшилися на 218,67 дол. США або на 53,3 \%, величина сукупних доходів у 2016 р. зменшилася на 1891,76 дол. США або на 56,6 \%, розмір ВВП на душу населення у 2015 р. знизився на 18887,8 дол. США або на $47,2 \%$. На основі цього можемо говорити про загрозу фінансовому станові людини та про зубожіння нації, оскільки рівень іiі добробуту знизився в середньому на 53,7 \%. Таку ситуацію можна пояснити багатьма чинниками, зокрема: збройний конфлікт на сході та півдні нашої країни, падіння грошової одиниці, складне економічне становище та ін. Упродовж 2016-2018 рр. ситуація дещо покращується, проте рівень 2013 р. ще недосяжний (рис. 1).

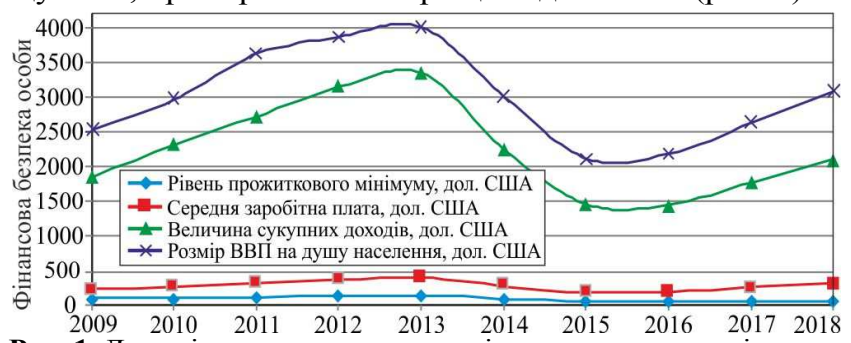

Рис. 1. Динаміка основних показників, що визначають рівень фінансової безпеки особи

Варто зауважити, що аналіз кожного показника із системи показників не дає цілісної картини та малопридатний для здійснення комплексної оцінки реального стану досліджуваного об'єкта і для здійснення міжрегіональних та міжнародних порівнянь, оскільки методологія розрахунку окремих показників у різних системах досить часто відрізняється. Тому на сьогодні дедалі більшої актуальності набувають питання побудови єдиного інтегрального показника, за яким визначали б рівень фінансової безпеки особи, застосування якого дало б змогу дати однозначну характеристику рівня та динаміки розвитку суспільства. Для розрахунку інтегрального показника всі дані, індикатори та індекси вимірюються за допомогою різних фізичних величин, мають різні інтерпретації та змінюються в різних діапазонах (Khapov, 2015). Тому ми їх пронормували так, що їх значення знаходилися в діапазоні від 0 до 1 , перед тим розділивши на стимулятори та дестимулятори. Провівши відповідні розрахунки, отримали значення інтегрального індексу фінансової безпеки особи (рис. 2).

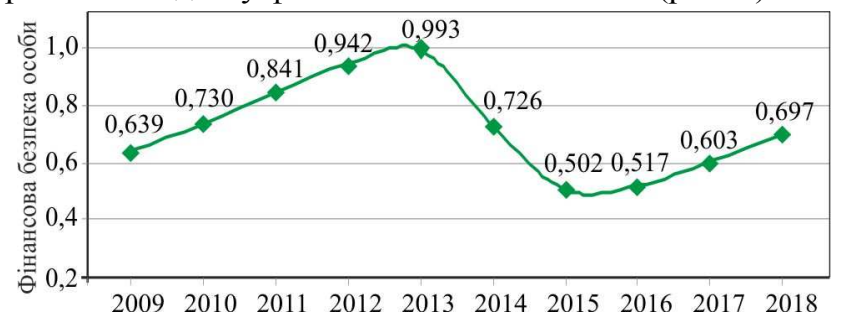

Рис. 2. Інтегральний показник фінансової безпеки особи

Отримавши загальний інтегральний показник фінансової безпеки особи впродовж 2009-2018 рр., можна проаналізувати його динаміку та визначити стан добробуту людей. Як бачимо з рис. 2, упродовж 2013-2015 pр. відбулося стрімке падіння узагальненого показника, а зараз ситуація плавно покращується (іде зростання показника, хоч і повільними темпами).

Соціальні чинники, звісно, мають беззаперечний вплив на фінансову безпеку особи, бо безробіття, бід- 
ність, диференціація доходів та інші ризики створюють перешкоди до нормального функціонування людини, забезпечення іiі фізіологічних потреб. Проте, на нашу думку, також важливе значення мають і психологічні чинники. Понад це ми вважаємо, що між фінансовою безпекою особи та іiї психологічною безпекою існує тісна двостороння залежність, бо чим вищий рівень психологічної безпеки, тим людина більше задоволена своїм життям і має можливості до власного розвитку, досягнення поставлених цілей та ефективного використання власного потенціалу, що є запорукою її фінансової стабільності, а низький рівень фінансової безпеки особи, водночас, негативно впливає на психологічне становище індивіду.

На наш погляд, психологічна безпека особистості це стан захищеності людей від впливів, загроз та небезпек, які можуть погіршити внутрішній стан людини, зменшити іiї адаптацію в соціумі та розкриття власного потенціалу. На сьогодні $є$ дуже багато чинників, які впливають на психологічну безпеку особистості, порушуючи іiі психологічний клімат і навіть можуть бути загрозою для здоров'я людини. Саме тому визначення загроз психологічній безпеці та уникнення їх має досить вагоме значення на шляху до психологічного здоров'я.

Агузумцян Р. В. , Мурадян Е. Б. виділяють такі чинники психологічної безпеки особистості: чинники об'єктивного порядку (забезпечують психологічну безпеку особистості на рівні індивідуума, які залежать від культурно-історичного розвитку суспільства); чинники об'єктивно-суб'єктивного порядку (визначають психологічну безпеку особистості як соціального типу: особистісний потенціал адаптивних можливостей людини в межах соціально прийнятних моральних норм, уміння розуміти і приймати інших, бути соціально значущим серед інших, прийнятим іншими; чинники суб'єктивного порядку (забезпечують психологічну безпеку особистості як індивідуальності: мотиваційно-смислові ставлення особистості) (Aguzumtcian, \& Muradian, 2009).

Зазначимо, що чинники суб'єктивно-об'єктивного порядку та чинники суб'єктивного порядку передбачають досягнення особистістю своєї межі потреб, своїх цілей, соціалізації. Серед загроз, які значно впливають на всі чинники психологічної безпеки особистості, можна виділити: інформаційно-психологічні загрози, професійна діяльність, яка не збігається із вподобаннями, психологічне насильство у професійному середовищі, авторитарний стиль керівника, який не дає розкритись потенціалу працівника, або професійне вигорання.

Серед професій, які підлягають професійному вигоранню, на першому місці є педагоги. Л. М. Молчанова отримала результати дослідження, які свідчать про специфічне проектування профілю професійної діяльності викладачів вишів у контексті професійної успішності на розвиток стану психічного вигоряння, який виявляється в асинхронній динаміці всіх його фаз у старших викладачів і доцентів зі стажем професійної діяльності від 5 до 10 років, причому більш виражений у доцентів. Асинхронне напруження більше виявлене у доцентів, чия тривалість професійної діяльності не перевищила 10 років, ніж у старших викладачів, і також більше у доцентів 3 тривалістю професійної діяльності від 5 до 10 років і понад 10 років, ніж у професорів. Окрім цього, у молодих викладачів порівняно зі старшими спостерігається значущо високе асинхронне виснаження психоемоційних ресурсів (Molchanova, 2011).

Зазначимо, що на фінансову та психологічну безпеку особи вагомий вплив також має ставлення людини до грошей, їі здатність до заощадження, пошуку джерел фінансування. В Україні процес формування у людей ставлення до грошей, на думку В. Москаленко, $\epsilon$ під впливом різних тенденцій. Першою тенденцією дослідниця вважає традиційну економічну свідомість, пов'язану з ідеєю соціальної рівності, сприйняттям грошей як абстрактної цінності, про яку неохоче говорять. До другої тенденції вона зараховує радянський менталітет, в якому закладено образ грошей як засіб експлуатації і нерівності, якого потрібно позбутися. Третя - це вплив західного економізму, який ставить грошові відносини у центр суспільства. Та четверта тенденція - це кризовий характер економіки. Взаємодія цих чотирьох тенденцій і визначає особливий тип монетарної культури нашого суспільства (Moskalenko, 2004).

Лі С. , Веблей П. та Велкер С. у дослідженнях проблеми заборгованості виділили низку чинників, що впливають на поведінку, яка призводить до заборгованості. На їхню думку, до таких чинників можна зарахувати позитивне соціальне ставлення до боргів. Це пов'язують iз розповсюдженням такого явища, як кредит, який вважають оптимальним засобом отримання коштів для купівлі товарів та послуг. Також одним із таких чинників $\epsilon$ процес економічної соціалізації, тобто, якщо в сім'ї заборгованість вважається допустимим явищем, то це породжує таку ж модель поведінки у наступних поколіннях. На процес породження заборгованості теж впливає соціальне порівняння, тоді коли людина порівнює себе 3 невідповідною, за фінансовими можливостями, референтною групою, бажаючи в такий спосіб бути такою, "як усі". На поведінку, яка призводить до заборгованості, можуть впливати й такі чинники, як невміння розпоряджатися власними фінансовими ресурсами, нераціональна споживацька поведінка, ставлення до боргів, а також зовнішній локус контролю особистості (Fenko, 2000).

Висновки. Підсумовуючи все наведене вище, можемо сказати, що така категорія, як "фінансова безпека особи" - комплексний показник, зміст якого не може обмежуватися винятково рівнем доходів, а концентрує в собі, поряд із економічною та соціальною складовими, також психологічну. Кінцевою метою інтегрального індексу фінансової безпеки $є$ можливість комплексно, всебічно та об'єктивно оцінити рівень добробуту населення та здійснення міжрегіональних та міжнародних порівнянь, що проявлятиметься у ранжуванні регіонів і країн за рівнем фінансової стабільності жителів.

До ключових напрямів підвищення рівня фінансової та психологічної безпеки особи можна віднести: економічна стабільність у країні; достойна та конкурентна на міжнародній арені заробітна плата; зменшення диференціації доходів населення; подолання бідності та зменшення рівня безробіття; зростання ВВП; виховання у майбутньому поколінні монетарної культури, позитивного ставлення до грошей, здатності до заощаджень та об'єктивного ставлення до боргів; розкриття особистісного потенціалу; визначення власної місії і цілей; вибір професії залежно від вмінь та вподобань; попередження професійного вигорання. 
Реалізація перелічених напрямів допоможе підвищити рівень фінансової безпеки особи та виховати нове покоління фінансово грамотним та психологічно стійким, що забезпечить своєю чергою добробут нації та економічне зростання країни загалом.

\section{Перелік використаних джерел}

Aguzumtcian, R. V., \& Muradian, E. B. (2009). Psikhologicheskie aspekty bezopasnosti lichnosti. Vestnik prakticheskoi psikhologii obrazovaniia, 2(19), 40-44. [In Ukrainian].

Fenko, A. (2000). Problema deneg v zarubezhnykh psikhologicheskikh issledovaniiakh. Psikhologicheskii zhurnal, 1, 50-62. [In Russian].

Khapov, D. V. (2015). Analiz intehralnoho pokaznyka yakosti zhyttia naselennia. Ekonomichnyi analiz, 19(1), 101-107. [In Ukrainian].

Molchanova, L. N. (2011). Sostoianie psikhicheskogo vygoraniia u pedagogov vysshei shkoly v kontekste professionalnoi uspeshnosti.
Vestnik Tomskogo gosudarstvennogo universiteta, 348, 128-132. [In Russian].

Moskalenko, V. (2004). Suchasni napriamky doslidzhen v ekonomichnii psykholohii. Sotsialna psykholohiia, 3(5), 3-21. [In Ukrainian].

Papusha, N. S. (2011). Finansova bezpeka osoby: henezys. Naukovi pratsi Kirovohradskoho natsionalnoho tekhnichnoho universytetu, 19, 230-234. [In Ukrainian].

Veb-storinka. (2019). Ofitsiina veb-storinka Derzhavnoi sluzhby statystyky Ukrainy. Retrieved from: http:/www.ukrstat.gov.ua. [In Ukrainian].

Yermoshenko, M. M. (2015). Finansova bezpeka derzhavy: natsionalni interesy, realni zahrozy, stratehiia zabezpechennia: monohrafiia. Kyiv: Nats. torh.-ekon. un-t, 240 p. [In Ukrainian].

Zavhorodnia, N. V. (2014). Vymiriuvannia bidnosti v Ukraini. Zbirnyk naukovykh prats Tavriiskoho derzhavnoho ahrotekhnolohichnoho universytetu. Ekonomichni nauky, 4(28), 189-196. [In Ukrainian].

N. V. Halaiko, O. O. Stoliarenko

Lviv State University of Internal Affairs, Lviv, Ukraine

\section{INFLUENCE OF SOCIAL AND PSYCHOLOGICAL FACTORS ON FINANCIAL SAFETY OF A PERSON}

The article deals with the main approaches to the interpretation of the concept "financial security of a person" and provides an actual interpretation of this category. It is noted that ensuring the financial security of a person has a significant impact on the financial security of the state and vice versa, because under instability it is impossible to solve economic problems without providing financial security for citizens. In researching the factors of influence on the financial security of a person, attention is focused on social and psychological factors, in particular, since the magnitude of total incomes per capita, the level of remuneration, psychological attitude to money and debt are factors that definitely affect the financial security of a person and form his/her future well-being. In the course of our study, the integral index of financial security of a person is calculated. In determining this general indicator, indicators such as the subsistence level, wages (average wages), the value of aggregate income per person, income disaggregation (quintile ratio of funds) and per capita GDP were researched in the dynamics during 2009-2018. A clear relationship between financial security of a person and his/her psychological safety is established. It is noted that there is an interconnection here, because the low level of financial security of a person negatively affects psychological safety, and vice versa. The higher the level of psychological safety, the more the person is satisfied with his/her life and is able to own development, achievement of the set goals and effective use of his/her own potential, which is the key to his/her financial stability. Moreover, the attention is drawn to the fact that the person has a significant influence on the financial and psychological security of a person's attitude towards money, his/her ability to save money, the search for sources of funding, and four trends in the formation of a monetary culture. Authors' own conclusions are formed and indicated on the main directions of raising the level of financial and psychological security of a person.

Keywords: financial security of a person; psychological security of a person; integral index of financial security of a person; man's attitude to money; the subsistence level; average wages. 